\title{
EFEKTIVITAS PENAMBAHAN KARBON AKTIF ARANG KAYU BAKAU DALAM PROSES FILTRASI AIR GAMBUT
}

\author{
Nila Puspita Sari ${ }^{1}$, Mashuri ${ }^{2}$ \\ Prodi Sarjana Kesehatan Masyarakat, STIKes Hang Tuah Pekanbaru \\ nps@htp.ac.id ${ }^{\mathbf{1}}$, maaashuri@gmail.com ${ }^{2}$
}

\begin{abstract}
Peat water can cause diseases such as cholera, hepatitis, dysentery, skin and eye diseases and digestive diseases. Peat water is a source water which is used for daily needed by society in Segomeng. Mangrove wood is a material that can be used in the process of water purification because it can be used as activated charcoal which is a carbon compound, which is produced from a material that contain a carbon. The research purpose is to knowing whether activated carbon of mangrove wood charcoal can be a medium of peat water filtering into clean water. This research type is experiment and design of this research use Complete Random Design with some treatment which are arranged randomly for all experimental units. The different treatments are given, among others, using slow sand filtration and clay soil as coagulant, using slow sand filter with activated charcoal added from mangrove wood with a thickness of $10 \mathrm{~cm}$, and with a thickness of $15 \mathrm{~cm}$. The results showed filtration with the addition of activated charcoal from mangrove wood with a thickness of $15 \mathrm{~cm}$ in getting the best results, can increase the $\mathrm{pH}$ value and is expected to improve the water quality of the acidic, odor-free, reducing taste, and the rapid filtration process that is 10 minutes. The conclusion is that the addition of activated carbon from mangrove wood charcoal is quite effective in the process of peat water filtration and can improve physical quality of water. The Suggestion is, should be measured of physical, chemical and biological character of peat water before and after filtration process.and also measurement of absorption of activated carbon of charcoal of mangrove wood before used as absorbent in filtration process.
\end{abstract}

Keyword : Peat Water, Carbon Active, Mangrove Wooden

\begin{abstract}
ABSTRAK
Air gambut bisa menimbulkan penyakit seperti kolera, hepatitis,disentri, penyakit kulit dan mata serta penyakit pencernaan. Air gambut merupakan sumber air yang dipakai untuk kebutuhan sehari-hari masyarakat di Desa Segomeng. Kayu bakau merupakan bahan yang dapat digunakan dalam proses penjernihan air karena dapat dijadikan arang aktif yang merupakan senyawa karbon, yang dihasilkan dari bahan yang mengandung karbon. Tujuan penelitian ini adalah untuk mengetahui apakahkarbon aktif arang kayu bakau dapat menjadi media penyaringan air gambut menjadi air bersih. Jenis penelitian ini adalah eksperimen dan desain penelitian ini menggunakan Rancangan Acak Lengkap (RAL) dengan beberapa perlakuan.yang disusun secara random untuk seluruh unit percobaan. Perlakuan berbeda yang di berikan antara lain menggunakan filtrasi pasir lambat dan tanah lempung sebagai koagulan, menggunakan saringan pasir lambat dengan di tambahkan arang aktif dari kayu bakau dengan ketebalan $10 \mathrm{~cm}$, dan dengan ketebalan $15 \mathrm{~cm}$, Hasil penelitian menunjukan filtrasi dengan penambahan arang aktif dari kayu bakau dengan ketebalan $15 \mathrm{~cm}$ di dapatkan hasil yang paling baik, dapat menaikkan nilai $\mathrm{pH}$ dan diduga dapat memperbaiki kualitas air yang bersifat asam, menghilangkan bau, mengurangi rasa, dan proses filtrasinya cepat yaitu 10 menit. Kesimpulannya adalah penambahan karbon aktif dari arang kayu bakau cukup
\end{abstract}


efektif dalam proses filtrasi air gambut dan dapat memperbaiki kualitas fisik air. Saran sebaiknya dilakukan pengukuran karakter fisik, kimia dan biologi air gambut sebelum dan sesudah melakukan proses filtrasi.dan juga pengukuran daya serap karbon aktif arang kayu bakau sebelum digunakan sebagai absorben dalam proses filtrasi.

Kata Kunci $\quad$ : Air Gambut, Karbon Aktif, Kayu Bakau

\section{PENDAHULUAN}

Air gambut adalah salah satu sumber air yang dapat dijadikan sebagai sumber air baku untuk air bersih bila dilakukan penyulingan atau filtrasi. Air gambut merupakan air permukaan yang ada di wilayah Kalimantan dan Sumatra. Karakteristik air gambut mempunyai intensitas warna merah kecoklatan, derajat keasaman tinggi (nilai $\mathrm{pH}$ rendah), kandungan zat organik tinggi, dan konsentrasi partikel tersuspensi dan ion rendah (Suherman, 2013).

Menurut Musadad (1998), mengatakan masalah air gambut dapat menimbulkan masalah kesehatan karena air gambut memiliki intensitas warna kecoklatan, nilai $\mathrm{pH}$ rendah, kandungan zat organik yang tinggi dan ion yang rendah. Air gambut bisa menimbulkan penyakit seperti kolera, hepatitis, disentri, penyakit kulit dan mata setra penyakit pencernaan.

Air gambut merupakan sumber air yang dipakai untuk kebutuhan sehari-hari oleh masyarakat pedesaan,salah satunya di Desa Segomeng. Oleh karena itu perlu adanya di lakukan penjernihan terlebih dahulu untuk merubah fisik air sebelum digunakan. Penjernihan yang selama ini sering digunakan adalah penjernihan dengan menggunakan bahan kimia yaitu disinfektan seperti klorin, kaporit dan tawas. Akan tetapi jika disinfektan tersebut digunakan dalam jangka panjang tentunya akan menimbulkan dampak atau resiko terhadap masyarakat baik itu jangka panjang maupun jangka pendek. Salah satu cara untuk mengurangi penggunaan disinfektan tersebut adalah dengan mencari alternatif lain untuk penjernihan air yang bersifat alami. Selama ini pengolahan dengan menggunakan bahan alami masyarakat belum banyak yang mengetahui, padahal sangat banyak tanaman atau tumbuhan yang dapat digunakan dalam proses penjernihan air secara alami, kayu bakau contohnya.

Kayu bakau merupakan salah satu bahan yang dapat digunakan dalam proses penjernihan air karena kayu bakau dapat dijadikan arang aktif. Arang aktif merupakan senyawa karbon, yang dapapat dihasilkan dari bahan-bahan yang mengandung karbon atau dari arang yang diperlakukan secara khusus untuk mendapatkan permukaan yang lebih luas. Luas permukaan arang aktif berkisar antara 300-3500 $\mathrm{m}^{2} / \mathrm{gram}$ dan ini berhubungan dengan struktur pori internal yang menyebabkan arang aktif mempunyai sifat sebagai adsorben (Sembiring,2003).

Dari hasil pengamat penulis di Desa Segomeng Kecamatan Rangsang barat yang merupakan salah satu kecamatan di Kabupaten Kepulauan Meranti dengan luas wilayah 241,60 $\mathrm{km}^{2}$, dimana daerah tersebut merupakan kawasan lahan gambut dan sebagian besar masyarakat berkebun, buruh dan berdagang. Khusus bagi masyarakat Desa Segomeng yang tinggal di daerah pasang surut dan berawa, air gambut yang terdapat di daerah tempat tinggalnya digunakan untuk memenuhi kebutuhan dalam kehidupan sehari-hari, seperti mandi, mencuci, memasak dan minum pun masih banyak yang menggunakan air gambut. Air gambut yang digunakan berasal dari sumur galian dengan ciri-ciri berwarna merah, coklat hitam dan keruh. 


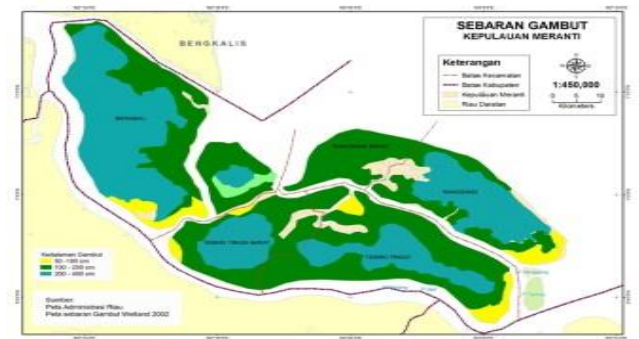

Gambar 1. Peta Sebaran Gambut Kepulauan Meranti

Arang aktif telah banyak digunakan dalam proses penyerapan warna Maupun penyerap senyawa-senyawa logam. Dalam hal ini peneliti mencoba menggunakan arang aktif dari kayu bakau, karena telah diketahui kayu bakau ini mempinyai berat jenis yang tinggi yaitu 1,02-1,05 serta termasuk kelas awet 1-3 dan kelas kuat 1 . Sehingga pembuatan arang aktif dengan menggunakan arang kayu bakau diharapkan akan menghasilkan arang aktif yang dapat menyerap zat warna dalam air gambut (Jauhari,2009).

Air minum seharusnya tidak berwarna untuk mencegah terjadinya keracunandari berbagai zat kimia $(\mathrm{pH})$ maupun mikro organisme. Derajat keasaman $\mathrm{pH}$ yang lebih besar dari 8,5 menyebabkan rasa tidak enak dan beberapa bahan kimia berubah menjadi racun yang menggangu kesehataan, zat organik sebagai $\mathrm{KMnO}_{4}$ yang berlebihan menimbulkan bau yang tidak sedap dan menyebabkan sakit perut. (Ristiana, 2009).

Penelitian sebelumnya oleh Fadillah (2016), membuktikan bahwa efektivitas penambahan karbon aktif cangkang kelapa sawit dalam proses filtrasi air sumur dari dua konsentrasi yaitu konsentrasi $10 \%$ dan $15 \%$ diperoleh hasil bahwa pada konsentrasi paling rendah $10 \%$ cukup efektif dalam proses filtrasi air sumur dan dapat memprrbaiki kualitas fisik air. Sementara penelitian lain dari Jauhari (2009), menyimpulkan bahwa penanggulangan kadar besi(Fe) air sumur menggunakan arang aktif kayu bakau dengan konsentrasi $8 \%, 10 \%$, dan $12 \%$ dapat menyerap kadar logam $(\mathrm{Fe})$ paling baik dan efektif yaitu pada konsentrasi $12 \%$.
Penelitian mengenai uji efektivitas arang aktif kayu bakau sebagai filtrasi air gambut belum pernah dilakukan. Berdasarkan hal tersebut, maka penulis tertarik untuk menguji potensi kemampuan arang aktif sebagai karbon aktif untuk filtrasi air gambut dengan konsentrasi pada kelompok perlakuan yaitu dengan ketebalan $10 \mathrm{~cm}$ dan $15 \mathrm{~cm}$. peneliti menggunakan bahan dari kayu bakau karena kayu bakau merupakan salah satu kekayaan lokal di Kabupaten Kepulauan Meranti. Peneliti juga menambahkan filtrasi pasir lambat dan juga tanah lempung sebagai koagulan alami.Tujuan penelitian ini adalah untuk untuk mengetahui apakah karbon aktif arang kayu bakau dapat menjadi media penyaringan air gambut menjadi air bersih.

\section{METODE}

Penelitian ini merupakan penelitan dalam bentuk eksperimen sungguhan (true experiment), yaitu tentang efektivitas penambahan karbon aktif arang kayu bakau dalam proses filtrasi air gambutDesain penelitian yang dilakukan yaitu menggunakan rancangan acak lengkap (RAL) rancangan acak lengkap dapat didefenisikan sebagai rancangan dengan beberapa perlakuan yang di susun secara random untuk seluruh unit percobaan. Penelitian ini akan dilakukan di Desa Segomeng Kecamatan Rangsang Barat Kabupaten Kepulauan Meranti Riau pada bulan Mei-Juni 2018. Target pada penelitian eksperimen ini yaitu air gambut yang ada di masyarakat Desa Segomeng Kecamatan Rangsang Barat Kabupaten Kepulauan Meranti, yang memiliki keriteria fisik mengalami kekeruhan, berwarna, berasa dan berbau.

\section{HASIL}

Penelitian ini dilakukan empat tahapan proses yaitu: penyiapan tanah lempung sebagai koagulan, penyiapan saringan dan analisis dari proses filtrasi 
dengan penambahan karbon aktif, percobaan yang berbeda yaitu Pembuatan saringan pasir dengan menggunakan filtrasi pasir lambat dan menggunakan paralon dengan diameter 4 tanah lempung sebagai koagulan, inci kemudian bahan-bahan disusun pada menggunakan saringan pasir lambat dengan gambar 7 dan kemudian di lakukan di tambahkan arang aktif dari kayu bakau penyaringan.

Uji efektivitas penambahan karbon aktif arang kayu bakau dalam proses filtrasi air gambut di gunakan rancangan acak lengkap (RAL) dengan 3 perlakuan dan 3 dengan ketebalan $10 \mathrm{~cm}$ dan menggunakan saringan pasir lambat dengan penambahan arang aktif dari kayu bakau dengan ketebalan $15 \mathrm{~cm}$. hasil analisis dari proses filtrasi adalah sebagai berikut:

\section{Warna atau Kekeruhan}

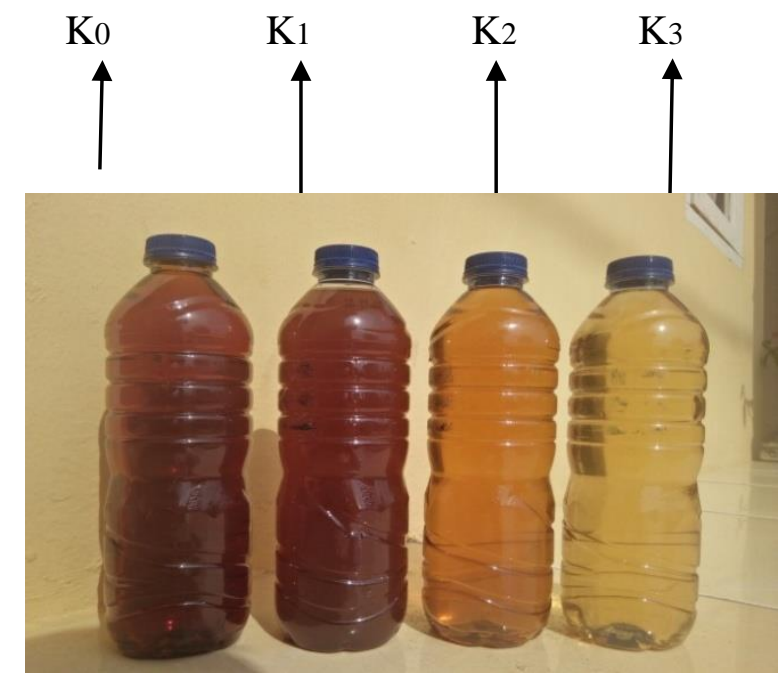

Gambar 1. Hasil proses penyaringan air gambut

Gambar 1 merupakan hasil dari pengamatan yang sudah dilakukan, dimana K0 merupakan air gambut tanpa perlakuan (kontrol), K1 adalah air gambung dengan penambahan tanah lempung dan pasir lambat, K2 adalah air gambut dengan penambahan pasir lambat dan arang aktif $10 \mathrm{~cm}$, dan $\mathrm{K} 3$ adalah air gambut dengan penambahan pasir lambat dan arang aktif $15 \mathrm{~cm}$.

Hasil analisa warna atau kekeruhan air gambut pada gambar 1 yaitu Air kontrol (K0) atau air gambut yang tidak melewati filtrasi terlihat sangat kuat sekali warna kecoklatannya, air yang melewati pasir dapat kita lihat pada gambar dengan penambahan tanah lempung sebagai koagulan terlihar warna sedikit berubah akan tetapi air menjadi sangat keruh di sebabkan tanah lempung (K1), selanjutnya filtrasi dengan menggunakan saringan pasir lambat dan dengan di tambahkan arang aktif dari kayu bakau dengan ketebalan $10 \mathrm{~cm}$ (K2) warna dari air gambut tersebut mulai berkurang dibanding air kontrol dan air yang di tambahkan tanah lempung, kemudian filtrasi menggunakan saringan pasir lambat dan ditambahkan karbon aktif dari arang kayu bakau dengan ketebalan $15 \mathrm{~cm}$ (K3) hasilnya sangat jernih dibanding yang sebelumnya, dengan demikian proses filtrasi dengan penambahan arang aktif dari kayu bakau dengan ketebalan $15 \mathrm{~cm}$ didapatkan hasil yang paling baik dan juga terdapat perbedaan yang signifikan terhadap setiap perlakuan. 
pH Air

Dari tabel 3 terlihat bahwa nilai $\mathrm{pH}$ yaitu sebagai berikut:

a. Air gambut $\left(\mathrm{K}_{0}\right)$

Air kontrol atau air gambut sebelum di beri perlakuan atau air gambut yang tidak melewati proses filtrasi sebesar 4,06.

b. Air gambut dengan penambahan tanah lempung (K1)

Proses filtrasi dengan penambahan tanah lempung dan pasir lambat didapatkan nilai pH yaitu 5,02.

c. Air gambut yang melewati filtrasi dan karbon aktif $10 \mathrm{~cm}\left(\mathrm{~K}_{2}\right)$

$\mathrm{pH}$ dari proses filtrasi dengan penambahan pasir lambat dan karbon aktif arang kayu bakau dengan ketebalan $10 \mathrm{~cm}$ yaitu 4,80 .

d. Air gambut yang melewati filtrasi dan karbon aktif $15 \mathrm{~cm}(\mathrm{~K} 3)$

Proses filtrasi menggunakan saringan pasir lambat dan dengan penambahan karbon aktif arang kayu bakau dengan ketebalan $15 \mathrm{~cm}$ didapatkan nilai $\mathrm{pH}$ adalah 5,85. Dengan demikian proses filtrasi dengan penambahan karbon aktif arang kayu bakau dapat menaik kan nilai $\mathrm{pH}$ dan diduga dapat memperbaiki kualitas air yang bersifat asam. Dan dapat dilihat pada tabel 3 bahwa terdapat perbedaan yang signifikan $\mathrm{pH}$ air sebelum dan sesudah melakukan proses filtrasi dengan penambahan tanah lempung maupun dengan penambahan karbon aktif arang kayu bakau.

\section{Bau Air}

hasil analisa bau pada air yang dirasakan oleh peneliti yaitu:

\section{a. Air Gambut (Ko)}

Air gambut atau air kontrol atau air yang belum melewati proses filtrasi masih berbau walaupun bau air tersebut tidak terlalu menyengat akan tetapi bau dari air tersebut seperti bau dari busukan kayu.

b. Air Gambut yang diberi Koagulan Tanah Lempung (K1)

Sedangkan bau dari air yang dicampur dengan tanah lempung dan melewati saringan pasir lambat hasilnya masih bau akan tetapi bau dari air ini sangat berbeda dengan air kontrol, bau dari air ini ada sedikit berbau tanah dari tanag lempung tersebut.

c. Air Gambut yang Melewati Filtrasi dan Arang Bakau $10 \mathrm{~cm}$ (K2)

Hasil analisia bau dari air yang melewati filtrasi pasir lambat dan dengan ditambahkan karbon aktif arang kayu bakau dengan ketebalan $10 \mathrm{~cm}$ ini sangat berbeda dengan hasil yang sebelumnya, hasil dari penambahan $10 \mathrm{~cm}$ karbon aktif arang kayu bakau ini bisa membuat air tidak berbau.

\section{d. Air Gambut yang Melewati} Filtrasi dan Arang Bakau $15 \mathrm{~cm}$ (K3)

Hasil analisa bau dari air yang melewati filtrasi pasir lambat dan dengan di tambahkan karbon aktif arang kayu bakau dengan ketebalan $15 \mathrm{~cm}$ ini sama hasilnya dengan penambahan karbon aktif arangkayu bakau 10 $\mathrm{cm}$, hasilnya juga tidak berbau.

\section{Rasa Air}

Hasil analisa rasa pada air gambut yaitu:

a. Nilai rasa pada air gambut kontrol atau air gambut yang belum 
melalui proses filtrasi yaitu air sangat berasa.

b. Nilai rasa dari air gambut yang beri penambahan tanah lempung sebagai koagulan dan melewati proses filtrasi saringan pasir lambat hasilnya lebih berasa dibanding air kontrol.

c. Nilai rasa dari air gambut yang melewati saringan pasir lambat dan diberi penambahan karbon aktif arang kayu bakau dengan ketebalan $10 \mathrm{~cm}$ yaitu hasilnya masih berasa akan tetapi rasa dari air ini lebih berkurang dibanding dengan air kontrol.

d. Nilai rasa dari air gambut yang melewati saringan pasir lambat dan diberi penambahan karbon aktif arang kayu bakau dengan ketebalan $15 \mathrm{~cm}$ yaitu hasilnya masih sedikit berasa akan tetapi rasa dari air ini lebih berkurang dibanding dengan air yang diberi penambahan karbon aktif arang kayu bakau dengan ketebalan 10 $\mathrm{cm}$.

\section{Waktu atau Lama Proses Filtrasi}

Hasil analisa perbedaan waktu atau lama proses filtrasi efektifitas penambahan karbon aktif arang kayu bakau dalam proses filtrasi air gambut adalah sebagai berikut:

\section{a. Air Gambut yang diberi Koagulan Tanah Lempung}

Analisa air gambut yang di beri penambahan tanah lempung sebagai koagulan dan melewati saringan pasir lambat hasilnya yaitu 18 menit.

b. Air Gambut yang Melewati Filtrasi dan Arang Bakau $10 \mathrm{~cm}$

Air gambut yang melewati filtrasi saringan pasir lambat dan diberi karbon aktif arang kayu bakau dengan ketebalan $10 \mathrm{~cm}$ hasil analisa waktu nya adalah 16 menit.

\section{c. Air Gambut yang Melewati Filtrasi dan Arang Bakau $15 \mathrm{~cm}$ Air gambut yang melewati filtrasi saringan pasir lambat dan diberi karbon aktif arang kayu bakau dengan ketebalan $15 \mathrm{~cm}$ hasil analisa waktu nya adalah 20 menit.}

\section{PEMBAHASAN}

Setelah udara air adalah zat yang sangat penting dalam kehidupan seharihari.Tiga perempat daribagian tubuh kita terdiri atas air oleh karena itu manusia sangat bergantung pada air dantidak seorangpun dapat bertahan hidup lebih dari 5 hari tanpa minum air. Selain itu, air juga difungsikan untuk memasak, mencuci, mandi dan membersihkan kotoran yang ada di sekitar rumah. Air juga digunakan untuk keperluan industri, pertanian, pemadam kebakaran, tempat rekreasi, transportasi dan lainnya (Fadilah dan Wahyuni, 2016). Seiring dengan perkembangan zaman sangat sulit untuk mendapatkan kualitas air yang baik akibat banyaknya pencemaran-pencemaran yang di sebabkan oleh masyarakat yang kurang perduli terhadap lingkungan, yang menyebabkan kualitas air menjadi menurun.

Kusnaedi (2010), menyatakan bahwa untuk jangka pendek kualitas air yang tidak baik dapat mengakibatkan muntaber, diare, kolera, tipus atau disentri.Hal ini dapat terjadi pada keadaan sanitasi lingkungan yang kurang baik. Bila air tanah dan air permukaan tercemar oleh kotoran, maka mikroorganisme akan tersebar ke sumber air yang dipakai untuk keperluan rumah tangga, karena dalam kegiatan sehari-hari masyarakat pada umumnya masih banyak menggunakan air sumur sebagai sumber persedian air seperti diperdesaan. Kebutuhan air masyarakat pedesaan umumnya masih tergantung pada sumber air alami.

Arang aktif merupakan salah satu bahan yang digunakan sebagai penyerap 
kotoran pada air. Arang aktif sangat berpotensi untuk mengurangi bahkan menghilangkan kotoran-kotoran pada air yang dapat menimbulkan berbagai penyakit pada manusia (Sembiring dan Sinaga, 2003).

Peneliti bermaksud ingin mengetahui efektivitas karbon aktif dari arang kayu bakau dalam proses filtrasi air gambut di Desa Segomeng Kecamatan Rangsang Barat, dengan menggunkan rancangan acak lengkap untuk mengetahui berapa efektif karbon aktif arang kayu bakau dalam memperbaiki kualitas air dari segi fisiknya. Berdasarkan hasil penelitian pada gambar dan tabel di atas menunjukkan bahwa perlakuan yang berbeda pada proses filtrasi memberikan hasil yang berbeda pula terhadap kekeruhan, $\mathrm{pH}$, bau, rasa dan waktu pada air tersebut.

\section{Warna atau Kekeruhan}

Terjadinya kekeruhan dan berwarna pada air disebabkan karena air tersebut mengandung begitu banyak partikel bahan yang tersuspensi. Bahan-bahan yang menyebabkan terjadinya kekeruhan tersebut yaitu bahan-bahan organik yang tersebar, tanah liat, lumpur, dan partikel-partikel kecil yang tersuspensi lainnya. Kekeruhan merupakan sifat optis dari suatu larutan, yaitu hamburan dan absorpsi cahaya yang melaluinya (Suhartana,2006).

Analisis tingkat kekeruhan atau warna atau kekeruhan air gambut terlihat bahwa pegukuran tingkat kekeruhan dengan proses filtrasi terjadi penurunan yang cukup tinggi. Mengingat fungsi dari saringan pasir lambat dan juga arang aktif sebagai alat penyaring dan penyerap dari partikel-partikel air gambut tersebut. Kalau kita lihat pada gambar 8 penyerapan yang paling optimal adalah dengan penambahan karbon aktif dari arang kayu bakau $15 \mathrm{~cm}$.

Mubarak dan Cahyatin (2008), mengatakan salah satu upaya untuk membersihkan air sumur yang keruh dan berwarna adalah dengan cara penyaringan dengan membuat saringan pasir lambat yang diisi dengan kerikil, ijuk, dan pasir. Selanjutnya dengan penambahan arang aktif untuk memberikan hasil yang optimal dalam proses penyaringan karena fungsi dari arang aktif sebagai penyerap.

Penelitian Fadilah dan Wahyuni (2016), yang berjudul efektivitas penambahan karbon aktif cangkang kelapa sawit sebagai penjernih air sumur, kualitas air yang telah dijernihkan dengan arang aktif menghasilkan penurunan yang paling baik yaitu pada konsentrasi arang aktif $10 \mathrm{~cm}$.

\section{pH (Derajat Keasaman)}

Derajat keasaman $(\mathrm{pH})$ digunakan untuk menyatakan tingkat keasaman atau kebasaan yang dimiliki oleh suatu larutan. Larutan bersifat asam apabila nilai $\mathrm{pH}$ di bawah 7 dan bersifat basa jika nilai $\mathrm{pH}$ di atas 7 . Dampak dari air yang bersifat asam yaitu dapat menyebabkan gatal-gatal, diare, dan kulit bersisik (Suhendra, 2010).

Berdasarkan hasil yang di peroleh pada tabel 3 terlihat pada proses filtrasi tanpa penambahan arang aktif terjadi penurunan nilai $\mathrm{pH}$, sedangkan pada proses filtrasi dengan penambahan arang aktif terjadi penambahan nilai $\mathrm{pH}$ yang cukup tinggi dengan demikian selain digunakan sebagai bahan penyerap di duga arang aktif juga dapat digunakan untuk menaikkan atau meningkatkan nilai $\mathrm{pH}$ pada air. Jadi, dapat disimpulkan proses filtrasi dengan penambahan karbon aktif arang kayu bakau cukup baik untuk memperbaiki kualitas air yang bersifat asam.

Sudirjo (2006), mengatakan gugus fungsi dapat terbentuk pada karbon aktif ketika dilakukan aktifasi 
yang terjadi interaksi radikal-radikal pada permukaan karbon dengan atomatom seperti oksigen dan nitrogen, yang berasar dari pengolahan ataupun atmosfir. Gugus fingsi ini menyebabkan permukaan karbon aktif ini menjadi reaktif secara kimiawi dan mempengaruhi absorpsinya. Oksidasi permukaan dalam produksi karbon aktif akan menghasilkan hidroksil, karbonil dan karboksilat yang memberikan sifat amfoter pada karbon, sehingga karbon aktif dapat bersifat asam maupun basa.

Seperti pada penelitian Suherman D, (2013), yang berjudul menghilangkan warna dan zat organik air gambut dengan metode koagulasi, akan tetapi koagulasi yang di maksud suherman yaitu koagulasi dari tawas bukan dari tanah lempung dan hasil yang di dapat malah air menjadi basa.

\section{Bau Air dan Rasa Air}

Berdasarkan keterangan hasil analisis mengenai bau bahwa dengan penambahan karbon aktif arang kayu bakau dapat menghilangkan bau pada air tersebut. Ini disebabkan pada proses filtrasi partikel-partikel yang dapat menyebabkan bau pada air tersebut sudah tersaring dan fungsi daripada arang aktif tersebut sebagai penyerap yang dapat menghilangkan bau pada air.

Hasil analisis mengenai rasa menunjukkan bahwa pada proses filtrasi dengan penambahan karbon aktif arang kayu bakau menghasilkan air yang tidak berasa, ini disebabkan bau lumpur atau partikel lain yang ada pada kontrol telah disaring dan diserap dengan arang aktif sehingga menghasilkan rasa dari air tersebut dan memenuhi standar air bersih.

Suhartana (2006), mengatakan pada umumnya arang aktif digunakan sebagai bahan penyerap dan penjernih. Dalam jumlah kecil digunakan juga sebagai katalisator.Sifat absorpsinya selektif, tergantung pada besar atau volume pori-pori dan luas permukaan. Daya serap arang aktif itu sangat besar, yaitu 25-100 persen terhadap berat arang aktif.Sehingga arang aktif dapat menyerap partikel-partikel yang dapat menimbulkan bau dan rasa pada air, sehingga dapat menghilangkan bau dan rasa pada air tersebut.

Penelitian sejenis dengan penelitian Fadilah dan Wahyuni (2016), yang berjudul efektivitas penambahan arang aktif cangkang kelapa sawit dalam proses filtrasi air sumur yang menghasilkan air menjadi tidak berbau dan tidak berasa, akan tetapi air yang di teliti sangat berbeda karna yang di teliti yaitu air sumur bukan air gambut.

\section{Dampak Air Gambut Terhadap Kesehatan}

Selanjutnya Suhendra (2010), mengatakan di dalam penelitiannya bahwa air yang diperlukan untuk memenuhi kebutuhan rumah tangga harus jernih. Air yang berwarna berarti mengandung bahan-bahan lain yang berbahaya bagi kesehatan. Sebaiknya air minum tidak berwarna untuk alasan keindahan dan agar dapat mencegah terjadinya keracunan yang diakibatkan dari berbagai zat kimia yang terkandung di dalamnya.Air gambut merupakan air yang memiliki sifat berwarna, berasa, berbau dan memiliki nilai $\mathrm{pH}$ yang rendah (asam), hal tersebut dikarenakan air gambut mengandung senyawa organik terlarut sehingga sebelum dikonsumsi ada baiknya untuk melakukan suatu pengolahan khusus pada air gambut tersebut. Senyawa organik ini terbentuk karena adanya pembusukan tanaman dan hewan yang sangat tahan terhadap mikriorganisme dalam waktu yang cukup lama. Penggunaan air gambut dengan tidak diolah terlebih dahulu bisa mengakibatkan dampak langsung seperti diare dan gatal-gatal, 
tetapi ada juga yang tidak berdampak langsung dalam artian dalam jangka waktu puluhan tahun karena akumulasi unsur-unsur kimia yang terdapat pada tubuh yang memerlukan pemeriksaan lebih mendetail untuk mengetahui dampak jangka panjang tersebut seperti kerusakan pada hati dan ginjal.

Secara keseluruhan penambahan karbon aktif arang kayu bakau dalam proses filtrasi cukup efektif dalam memperbaiki kualitas fisik air gambut. Selain itu fungsi dari saringan pasir sebagai penyaring air, sehingga penambahan karbon aktif arang kayu bakau memberikan hasil yang lebih optimal dalam meningkatkan kualitas air gambut. Tentunya hal ini sangat bermanfaat bagi masyarakat untuk meningkatkan kualitas air gambut untuk aktivitas sehari-hari. Pada tingkat kekeruhan atau warna terdapat hasil yang signifikan yang artinya terdapat perbedaan yang signifikan antara warna atau kekeruhan sebelum dan sesudah melakukan proses filtrasi. Pada $\mathrm{pH}$ air juga terdapat perbedaan yang signifikan dari $\mathrm{pH}$ 4,06 hingga naik menjadi 5,85 walaupun $\mathrm{pH}$ dari pengolahan air gambut ini belum menjadi $\mathrm{pH}$ normal akan tetapi ada perbedaan sebelum dan seudah melakukan proses filtrasi.

\section{KESIMPULAN}

Berdasarkan hasil dan pembahasan dari penelitian efektivitas penambahan karbon aktif arang kayu bakau dalam proses filtrasi air gambut ini dapat ditarik beberapa kesimpulan sebagai berikut, Karbon aktif dari arang kayu bakau dapat digunakan untuk proses filtrasi air gambut. Penambahan karbon aktif dari arang kalu bakau cukup efektif dalam proses filtrasi air gambut dan dapat memperbaiki kualitas fisik air gambut.Semakin tebalnya arang aktif kayu bakau dalam proses filtrasi, maka waktu untuk mendapatkan hasil air bersih semakin lambat, akan tetapi hasil air filtrasi akan menjadi lebih bersih.

\section{DAFTAR PUSTAKA}

Fadilah, M. \& Wahyuni, D. (2016). Efektivitas Penambahan Karbon Aktif Cangkang Kelapa Sawit (Elaeis Guineensis) Dalam Proses Filtrasi Air Sumur. Jurnal Kesehatan Komunitas, Vol. 3, No. 2, Mei 2016. Diakses 30 januari 2018, 11:18 wib.

Jauhari, A. (2009). Penanggulangan Kadar Besi (Fe) Air Sumur Menggunakan Arang Aktif Kayu Bakau (Rhizophora Mucronata Lamck) Dengan Aktivator Natrium Karbonat 5\%.Jurnal Hutan Tropis Borneo No. 28, Edisi Desember 2009. Diakses 08 april 2018, 10:55 wib.

Kusnaedi. (2010). Pengolahan Air Kotor Untuk Air Minum. Jakarta: PENEBAR SWADAYA.

Mubarak, W.I. \& Chayatin, N. (2008). Ilmu Kesehatan Masyarakat. Gersik: SALEMBA MEDIKA.

Musadad, D.A. (1998). Pengaruh Air Gambut Terhadap Kesehatan Dan Upaya Pemecahannya. Media litbangkes Vol. VIII No. 01/1998. Diakses 08 april 2018, 10:44 wib.

Ristiana, N. (2009). Efektivitas Ketebalan Kombinasi Zeolit Dengan Arang Aktif Dalam Menurunkan Kadar Kesadahan Air Sumur. Jurnal Kesehatan ISSN 1979-7621, VOL. 2, No. 1. Juni 2009. Diakses 17 juli 2018 .

Sembiring \& Sinaga. (2003). Arang Aktif. Jurnal Fakultas Teknik. Universitas Sumatra. Diakses 08 april 2020, 
Sudirjo. E. (2006). Penentuan Distribusi Benzema - Toluena Pada Kolam Absorbsi Fixed - Bed Karbon Aktif. Fakultas Teknik UI.Diakses 17 mei 2020.

Suhartana. (2006). Pemanfaatan Tempurung Kelapa Sebagai Bahan Baku Arang Aktif Dan Aplikasinya Untuk Penjernihan Air Sumur Di Desa Belor Kecamatan Ngaringan Kabupaten Grobokan. Jurnal ISSN : 1410-9662 Vol 9 No 3. UNDIP. Diakses 17 juli 2018.

Suhendra, D. \& E.R. Gunawan. (2010). Pembuatan Arang Aktif Dari Batang Jagung Menggunakan Aktivator Asam Sulfat Dan Penggunaan Dalam Ion Tembaga (II). Jurnal MAKARA, SAIN Vol 14 NO 1 : 2226 Mataram. Diakses 17 juli 2018.

Suherman. D. \& sumawijaya. N. (2013). Penghilangan Warna Dan Zat Organik Air Gambut Dengan Metode Koagulasi-Flokulasi Suasana Basa. Jurnal RISET Geologi Dan Pertambangan, Vol. 23, no. 2, desember 2013. Diakses 17 juli 2018 . 